\title{
The Gastrointestinal Bacteria of Mink (Mustela vison L): Influence of Age and Diet
}

\author{
By C. Williams ${ }^{1}$, J. Elnif ${ }^{2}$ and R.K. Buddington ${ }^{1}$ \\ ${ }^{1}$ Department of Bıological Sciences, Missıssıppı State Unıversity, Mississippı State, USA, ${ }^{2}$ Fur Anımal Science, \\ Department of Anımal Science and Anımal Health, The Royal Veterınary and Agricultural Unıversity, Denmark.
}

\begin{abstract}
Williams C, Elnif J, Buddington RK: The gastrointestinal bacteria of mink (Mustela vision L): Influence of age and diet. Acta vet. scand. 1998, 39, 473-482. Total numbers of aerotolerant and anaerobic bacteria, and densities of Enterobacteriaceae, lactobacill, staphylococc1, salmonella and shigella, and campylobacteria were enumerated in the contents of the stomach, small intestine (and the associated mucosa), and colon of mink beginning at 2 weeks of age to adulthood, and in adults that were fed diets with different levels and types of fiber or food deprived. Highest densities of all bacterial groups were found in the colon at all ages (up to $10^{8} \mathrm{cfu}$ per $\mathrm{g}$ for total anaerobes), but were 2-4 orders of magnitude lower than those of other mammals. When all regions were pooled, significant age-related increases $(p<0.05)$ were detected for anaerobes, aerobes, and staphylococc1, and these coincided with the dietary shift at weaning. Enterobacteriaceae did not vary with age. Lactobacill were never common 1solates, but were detected more often after weaning, partıcularly in adults fed diets containing the 2 sources of fiber. Campylobacteria were detected only at 2 weeks of age, and salmonella and shigella were not isolated from any of the experimental mink. Total bacterial densities, the relative proportions of the bacterial groups, and age- and diet-related effects differ from those known for other mammals, which may be related to the carnivorous diet and rapid movement of digesta through the GIT.
\end{abstract}

anaerobes; aerobes; enterics; stomach; small intestine; colon; fiber; development.

\section{Introduction}

The mammalian gastrointestinal tract (GIT) can be considered as a complex ecosystem. The stomach and the small and large intestines provide different habitats with distinct physical and chemical characteristics and different assemblages of bacteria. Similarly, the differences in GIT characteristics that exist between species of mammals are associated with species-specific assemblages of bacteria. The specialized populations of bacteria in the stomachs of ruminants provide a well known example. The various species of lactobacilli that have apparently adapted to the GIT characteristics of their host mammals (Tannock et al. 1987) provide another example.

Studies of omnivorous species, including humans, have shown there are postnatal changes in the composition of the bacteria present in the GIT (Swords et al. 1993). The successional changes start at birth when the sterile GIT is colonized by bacteria. Within just a few $h$ densities are comparable to those of adults. Initially, aerotolerant forms dominate, but these are gradually supplanted by anaerobic groups. 
Eventually, the normal adult bacterial assemblage is acquired.

The GIT bacteria are also responsive to dietary inputs. Although changing diet composition does not change the total densities of bacteria, this can alter the relative proportions of the different bacterial groups resident in the GIT. This is well known from comparison of the fecal flora of infants fed breast milk with those fed formula (Perman 1989). Some of the more dramatic changes in the GIT bacteria occur at weaning and coincide with changes in GIT structure and functions (Henning 1987).

There is much less known about the GIT bacteria of carnivores and the possible effects of age, diet, and region. We therefore examined the GIT bacteria of the strict carnivore mink, Mustela vison (Mustelidae), which has a GIT adapted for processing large quantities of protein, but little carbohydrate. The intestinal length of mink is 3-4 times longer than body length throughout the life history (Elnif 1987), which is short compared to the intestines of omnivorous mammals (Stevens 1988). Food transit times are very rapid in mink, averaging only 3$4 \mathrm{~h}$ in adults (Hansen 1978), and perhaps even shorter during suckling. We studied bacterial populations in the stomach, small intestine contents and mucosa, and colon from 2 weeks after birth to adulthood. In addition to total aerotolerant and anaerobic bacteria, we enumerated groups of bacteria that include representatives considered to be beneficial (lactobacilli) and pathogenic for some species of mammals (staphylococci, salmonella, shigella, and campylobacteria). The responses of the GIT bacteria to dietary inputs were examined directly in adult animals by feeding different diets and indirectly by comparing populations in suckled mink with those isolated from weaned and adult mink.

\section{Materials and methods}

Animals and their care

A total of 15 pregnant mink were obtained from a commercial producer (Zimbal Minkery, Oostburg, Wisconsin, USA) about 2 weeks prior to delivery. The animals were housed in facilities certified by the American Association for Accreditation of Laboratory Animal Care and maintained at $21-22^{\circ} \mathrm{C}$ with a $15: 9$ light dark cycle. Each animal was placed in a standard production cage with an attached nest box. Straw was made available for nest material and water was provided continuously by nipples.

Pregnant and lactating mink were fed twice each day a commercially available canned pet food that was considered adequate to meet energy and protein requirements (Chicken Formula Cat Food; Iams Company, Dayton, $\mathrm{OH}$ ). The energy content of the feed was $675 \mathrm{~kJ} / 100$ $\mathrm{g}(\sim 140 \mathrm{kcal} / 100 \mathrm{~g})$, and the distribution of energy (ME \%) was 35:55:10 for protein, fat, and carbohydrate, respectively. The use of a sterile canned food minimized bacterial contaminants that are prevalent in production diets prepared with offal and thereby minimized the contribution af bacteria that are not indigenous to the GIT.

The 14 mink kits used in the study were allowed to suckle for 6 weeks. Female mink normally begin to provide solid food to their kits at about 4 weeks of age. We attempted to reduce variation between litters by placing a small amount inside the nest box beginning at 4 weeks of age. The young mink were isolated from the mothers at 7 weeks and fed the solid diet exclusively thereafter.

The influence of diet on the GIT bacteria was examined in the adult female mink beginning at least 6 weeks after the kits had been weaned. Four treatments were used, including a control group fed the commercial diet $(n=4)$ and a second group that was deprived of food for $36 \mathrm{~h}$ $(n=4)$. The remaining 2 groups of mink were 
fed the commercial diet to which we added the insoluble, poorly fermented fiber cellulose $(\mathrm{n}=$ 3 ) or the soluble, more fermentable fiber oligofructose, abbreviated FOS $(n=4)$. Both fibers were added at a level of $10 \%$ of the dry weight of the diet.

\section{Sampling}

The mink kits were euthanized (Beuthanasia; Schering Plough; $1 \mathrm{ml} / 4.5 \mathrm{~kg}$, intracardiac) at postnatal weeks $2(n=4), 4(n=3), 6(n=3)$, and $8(n=4)$. The kits studied at each age originated from different litters. The adult females were sedated with ketamine (Ketaset; Bristol Laboratories; $0.1 \mathrm{ml} / \mathrm{kg}$; IM) before they were killed using Beuthanasia. Immediately after death the entire alimentary canal was removed. The stomach, a $5-10 \mathrm{~cm}$ segment of the small intestine from the mid point, and the entire colon were removed and placed into an anaerobic chamber within $5 \mathrm{~min}$ after death. Contents of the stomach, small intestine, and colon were collected, weighed, and placed in yeast broth diluent that had been reduced by placing it in the anaerobic chamber for at least $12 \mathrm{~h}$ prior to use (1:10; wt/vol). After removing the contents of the small intestinal segment, the mucosa was collected by gently scraping the segment with a glass slide and placed in the reduced yeast broth diluent.

\section{Microbiology}

The 4 samples were homogenized in the reduced yeast broth diluent and serial dilutions were prepared and plated using an autoplater (Spiral Biotech, Model 4000). Total anaerobes were enumerated on CDC anaerobe blood agar and total aerobes on tryptic soy agar with 5\% sheep blood (BBL; Becton-Dickinson Co., Cockeysville, MD). A lactobacillus-selective agar was used for the lactobacilli (Summanen et al. 1993). Enterobacteriaceae, staphylocoocci, salmonella and shigella, and campylobacteria were counted on MacConkey II agar (BBL), Mannitol Salt Agar (BBL), SalmonellaShigella Agar (BBL), and Campylobacter Agar (BBL), respectively. Aerobic plates were cultured in atmospheric conditions for 2-3 days and anaerobic plates in the chamber $(80 \% \mathrm{~N}$, $10 \% \mathrm{CO}_{2}, 10 \% \mathrm{H}_{2}$ ) for $4-5$ days. All plates were maintained at $37^{\circ} \mathrm{C}$. Representative colonies were identified by gram staining, colony morphology, aerotolerance, Crystal system (BBL), and gas chromatographic analysis of membrane fatty acids (Microbial Identification System; Newark, DE). Colony forming units (cfu) were normalized to wet weight of the samples.

\section{Statistics}

Values presented in tables are means and standard errors. The effects of age, diet, and region were determined by ANOVA of log transformed counts using the Statistical Analysis System (SAS Institute, Version 6.11; Carey, North Carolina). When a significant effect was detected, Duncan's test was used to identify specific differences between ages or regions.

\section{Results and discussion \\ Body mass and intestinal dimensions}

Body weights and intestinal dimensions of the developing and adult mink, including adult mink used for the diet studies, are presented in Table 1. Corroborating previous measurements (Elnif 1987), intestinal length during suckling when kits only had milk averaged $3.9 \pm 0.1$ times longer than body length, with a slight increase to $4.8 \pm 0.2$ at 6 and 8 weeks when the kits were making the transition to an exclusively solid food diet. When intestinal length was normalized to body mass $(\mathrm{cm} / \mathrm{g})$, values were highest at 8 weeks of age $(p<0.05)$, which was after weaning to the solid diet. Intestinal lengths of the adult mink fed the com- 
Table 1. Body weights and length, and intestınal lengths of the mink durıng postnatal development, and for adult mink food deprived for $36 \mathrm{~h}$ and fed the control diet alone (Adult/Control) or with added oligofructose (FOS) or cellulose Values with different superscript letters are significantly different with respect to age, and those with different numbers are different with respect to diet effects for the adults alone $(p<005)$. $P_{\text {Age }}$ is the $P$ value for the effect of age, from 2 weeks to adults, and $P_{\text {Diet }}$ is for the effect of diet for the adult mink.

\begin{tabular}{lccc}
\hline Age $(\mathrm{n})$ & Body Werght $(\mathrm{g})$ & Body Length $(\mathrm{cm})$ & Intestıne Length $(\mathrm{cm})$ \\
\hline 2 weeks (4) & $43 \pm 5^{\mathrm{a}}$ & -- & $48 \pm 4^{\mathrm{a}}$ \\
4 weeks (3) & $135 \pm 22^{\mathrm{b}}$ & $175 \pm 1.0^{\mathrm{a}}$ & $70 \pm 8^{\mathrm{b}}$ \\
6 weeks (3) & $311 \pm 23^{\mathrm{c}}$ & $24.5 \pm 0.3^{\mathrm{b}}$ & $117 \pm 8^{\mathrm{c}}$ \\
8 weeks (4) & $505 \pm 87^{\mathrm{d}}$ & $29.1 \pm 1.8^{\mathrm{c}}$ & $141 \pm 5^{\mathrm{d}}$ \\
Adults/Controls (4) & $1221 \pm 72^{\mathrm{e}}$ & $40.9 \pm 0.7^{\mathrm{d}}$ & $133 \pm 6^{\mathrm{d} 12}$ \\
Food Deprived (4) & $1147 \pm 145$ & $393 \pm 0.6$ & $123 \pm 9^{1}$ \\
Control + FOS (4) & $1193 \pm 118$ & $41.0 \pm 09$ & $129 \pm 4^{12}$ \\
Control + Cellulose (3) & $1288 \pm 114$ & $41.7 \pm 0.9$ & $144 \pm 5^{2}$ \\
$\mathrm{P}_{\text {Age }}$ & 0.0001 & 00001 & 00001 \\
$\mathrm{P}_{\text {Diet }}$ & 087 & 0.22 & 020 \\
\hline
\end{tabular}

mercial cat food were about $20 \%$ shorter than those measured previously from mink fed a production diet (Elnif 1987). The difference may be related to the amount of dietary fiber. The commercial cat food contains a maximum of $1.9 \%$ ash (reported analysis) whereas production diets fed to mink can have up to $6 \%-8 \%$ ash arising from indigestible diet components, such as plant materials, hair, and other poorly digested animal byproducts. Intestinal dimensions have been known to increase in other mammals when diets are supplemented with fiber (Addis 1932). However, the intestines of adult mink fed the diets with cellulose and FOS were not longer than those fed the control diet, but they were heavier.

\section{Bacteriology}

The adult GIT bacteria. Most of the research about the microbiota of mink has focused on the occurrence of suspected pathogens and the relations with health (Clausen 1988, Waechter \& Henriksen 1984). Salmonella and shigella are not known to be common 1solates in healthy mink. Corresponding with this, none were recovered from any region of the adult or developing mink examined in this study.
Previous reports show that bacterial densities in the intestines of adult mink are lower than those of mammals (Pedersen \& Jørgensen 1992, Jensen \& Clausen 1995). They are also lower than those we have enumerated in the intestines and fecal samples of cats (unpubl. data). The highest densities never exceeded $10^{8}$, and these were for total anaerobes in the colons of adult mink, which are st1ll at least 2 orders of magnitude lower than bacterial densities reported for omnivores (Swords et al. 1992) and the dog (Davis et al. 1977). Densities of total anaerobes in farm raised mink can be even lower (less than $10^{7}$ per ml; Jensen \& Clausen 1995). The low densities may be related to the rapid passage of food through mink intestine, which may not provide sufficient time for the bacterial assemblage to attain maximal densities. This may also explain the relatively high proportion of aerobes in the 4 sample sites. Even in the colon of adult mink, total densities of aerobes (1.52E8) were comparable to those for anaerobes (1.60E8). Furthermore, an unknown proportion of the anaerobic counts are likely to be facultative, not strict or obligate, anaerobes. In other species with longer transit times, obligate or strict anaerobes represent more than $90 \%$ of fe- 
cal bacteria, and in many species over $99 \%$. Corresponding with this, bacteroides are only $2 \%$ of the total bacterial population in the colons of mink (Jensen \& Clausen 1995). Interestingly, bacteroides counts were slightly higher in the small intestine of the mink.

Although oxygen tensions and redox potentials were not measured in the present study, and to our knowledge are not known for the mink, the rapid movement of food through the alimentary canal may not allow enough time for bacterial metabolism to provide an environment that is suitable for growth of anaerobes (i.e., low oxygen and high redox potential). Since anaerobes typically have longer cell cycle lengths than aerobes, it is not surprising that aerotolerant forms were numerically more abundant and represented a larger percentage of total bacterial counts than reported for other mammals.

There were regional differences for densities of staphylococci $(\mathrm{p}<0.02)$ and Enterobacteriaceae $(p<0.01)$, with densities highest in the more static contents of the colon. Regional effects were not detected for total anaerobes $(p>0.30)$, aerobes ( $p>0.15)$, and lactobacilli ( $p>0.70)$.

Bacterial populations during development. Densities of the bacterial groups at the different ages and in the 4 sample sites are presented in Table 2. Similar to other mammals, the GIT microbiota of mink exhibits age-related changes. The present study indicates that even though total densities of aerobes and anaerobes differ little between 2 weeks after birth and adulthood, there are shifts in the composition of the bacterial assemblage.

Campylobacteria were detected $\left(>10^{1} \mathrm{cfu} / \mathrm{gm}\right.$ wet weight) only at 2 weeks and in 7 of the 16 samples (in all 4 sites of one kit and in 2 stomachs and one colon of the remaining 3 kits). Lactobacilli were not common isolates during suckling with densities exceeding level of detection $\left(>10^{2}\right)$ in only $10 \%$ of the samples ex- amined (5 out of 50). These findings agree with those of other investigators (Pedersen et al. 1994) which indicate that the lactobacilli are not a common component of the normal mink GIT microbiota. Even though lactobacilli are not considered to be indigenous to the GIT of adult mink (Pedersen \& Jørgensen 1992), they were recovered slightly more frequently in weaned and adult mink (22\%; 7 out of 32 samples from the 8 week weaned juveniles and 4 adult mink fed the unaltered cat food).

Further comparisons of age effects are restricted to total anaerobes, aerobes, Enterobacteriaceae, and staphylococci, all of which were present in most, if not all, of the sample sites of the developing and adult mink.

When the 4 sample sites were pooled, age had a significant effect only on densities of staphylococci, with densities at 8 weeks exceeding those at all other ages. To obtain better insights about possible influences of the different diets consumed during development (milk vs solid food) we compared bacterial assemblages in the GIT of suckling kits $(2,4$, and 6 weeks combined) with pooled results for 8 week weaned juveniles and adult mink. Densities of staphylococci were markedly higher when only the solid diet was eaten. However, the proportions of aerobes and anaerobes represented by staphylococci did not differ between ages, regions, or feeding habits (suckling vs solid food). Other groups considered as lactic acid bacteria have been shown to increase after mink kits are weaned (Pedersen et al. 1994). In contrast, densities of Enterobacteriaceae tended to be higher during suckling $(\mathrm{p}<0.10)$. Age and feeding type (milk or adult diet) did not have significant effects on densities of total anaerobes and aerobes.

At all ages, the densities of the bacterial groups varied among the 4 sampling sites. The highest densities of anaerobes, aerobes, enterics, and staphylococci were found in the colon throughout development $(\mathrm{p}<0.05)$, with densities in the 
Table 2. Densities of anaerobes (Anaer), aerobes (Aer), Enterobacteriaceae (Enter), and staphylococci (Staph) in the 4 samples sites in mink at 2, 4, 6, 8 weeks of age and in adults (A). $P_{A g e}$ is the $P$ value for the effect of age in each of the 4 sample sites, and $P_{\text {Reg }}$ is for the effect of region. Values with different letter superscripts are significantly different with respect to age $(p<0.05)$.

\begin{tabular}{|c|c|c|c|c|c|c|}
\hline Group & Age & Stomach & $\begin{array}{l}\text { Small Intestine } \\
\text { Contents }\end{array}$ & $\begin{array}{l}\text { Small Intestine } \\
\text { Mucosa }\end{array}$ & Colon & $\mathbf{P}_{\mathrm{Reg}}$ \\
\hline \multirow[t]{6}{*}{ Anaer } & 2 & $1.34 \mathrm{E} 6 \pm 9.13 \mathrm{E} 5$ & $2.40 \mathrm{E} 5 \pm 2.40 \mathrm{E} 5$ & $5.60 \mathrm{E} 5 \pm 5.60 \mathrm{E} 5$ & $1.63 \mathrm{E} 7 \pm 9.59 \mathrm{E} 6$ & 0.16 \\
\hline & 4 & $6.73 \mathrm{E} 5 \pm 3.89 \mathrm{E} 5^{\mathrm{a}}$ & $1.60 \mathrm{E} 6 \pm 1.60 \mathrm{E} 6^{\mathrm{ab}}$ & $4.27 \mathrm{E} 4 \pm 2.98 \mathrm{E} 4^{\mathrm{a}}$ & $2.12 \mathrm{E} 8 \pm 1.34 \mathrm{E} 8^{\mathrm{b}}$ & 0.03 \\
\hline & 6 & $1.49 \mathrm{E} 6 \pm 7.36 \mathrm{E} 5$ & $1.45 \mathrm{E} 6 \pm 1.01 \mathrm{E} 6$ & $1.38 \mathrm{E} 6 \pm 8.07 \mathrm{E} 5$ & $7.60 \mathrm{E} 7 \pm 3.80 \mathrm{E} 7$ & 0.60 \\
\hline & 8 & $4.99 \mathrm{E} 6 \pm 3.07 \mathrm{E} 6$ & $1.51 \mathrm{E} 7 \pm 6.19 \mathrm{E} 6$ & $8.71 \mathrm{E} 6 \pm 3.08 \mathrm{E} 6$ & $8.71 \mathrm{E} 7 \pm 4.56 \mathrm{E} 7$ & 0.48 \\
\hline & A & $1.30 \mathrm{E} 7 \pm 1.29 \mathrm{E} 7$ & $1.43 \mathrm{E} 7 \pm 1.20 \mathrm{E} 7$ & $5.60 \mathrm{E} 6 \pm 5.53 \mathrm{E} 6$ & $1.60 \mathrm{E} 8 \pm 6.35 \mathrm{E} 7$ & 0.33 \\
\hline & $P_{\text {Age }}$ & 0.66 & 0.35 & 0.29 & 0.29 & \\
\hline \multirow[t]{6}{*}{ Aer } & 2 & $1.87 \mathrm{E} 6 \pm 7.64 \mathrm{E} 5^{\mathrm{ab}}$ & $2.98 \mathrm{E} 5 \pm 2.49 \mathrm{E}^{\mathrm{a}}$ & $7.04 \mathrm{E} 5 \pm 4.62 \mathrm{E}^{\mathrm{a}}$ & $9.31 \mathrm{E} 7 \pm 4.02 \mathrm{E} 7^{\mathrm{b}}$ & 0.05 \\
\hline & 4 & $4.42 \mathrm{E} 5 \pm 2.56 \mathrm{E} 5^{\mathrm{a}}$ & $9.38 \mathrm{E} 5 \pm 9.31 \mathrm{E} 5^{\mathrm{a}}$ & $1.94 \mathrm{E} 4 \pm 1.64 \mathrm{E} 4^{\mathrm{a}}$ & $2.04 \mathrm{E} 8 \pm 1.00 \mathrm{E} 8^{\mathrm{b}}$ & 0.03 \\
\hline & 6 & $6.07 \mathrm{E} 3 \pm 5.97 \mathrm{E} 3^{\mathrm{a}}$ & $7.44 \mathrm{E} 4 \pm 3.71 \mathrm{E} 4^{\mathrm{a}}$ & $1.08 \mathrm{E} 6 \pm 1.06 \mathrm{E} 6^{\mathrm{a}}$ & $6.59 \mathrm{E} 7 \pm 4.15 \mathrm{E} 7^{\mathrm{b}}$ & 0.04 \\
\hline & 8 & $1.95 \mathrm{E} 6 \pm 1.17 \mathrm{E} 6$ & $7.40 \mathrm{E} 6 \pm 2.75 \mathrm{E} 6$ & $4.73 \mathrm{E} 6 \pm 2.69 \mathrm{E} 6$ & $6.61 \mathrm{E} 7 \pm 2.48 \mathrm{E} 7$ & 0.43 \\
\hline & A & $2.92 \mathrm{E} 6 \pm 2.82 \mathrm{E} 6$ & $5.69 \mathrm{E} 6 \pm 3.41 \mathrm{E} 6$ & $6.57 \mathrm{E} 6 \pm 6.48 \mathrm{E} 6$ & $1.53 \mathrm{E} 8 \pm 5.09 \mathrm{E} 7$ & 0.17 \\
\hline & $\mathbf{P}_{\text {Age }}$ & 0.72 & 0.10 & 0.63 & 0.35 & \\
\hline \multirow[t]{6}{*}{ Enter } & 2 & $8.02 \mathrm{E} 4 \pm 4.53 \mathrm{E} 4^{\mathrm{a}}$ & $1.28 \mathrm{E} 4 \pm 9.35 \mathrm{E} 3^{\mathrm{a}}$ & $4.53 \mathrm{E} 5 \pm 2.61 \mathrm{E} 4^{\mathrm{a}}$ & $8.04 \mathrm{E} 7 \pm 4.07 \mathrm{E} 7^{\mathrm{b}}$ & 0.004 \\
\hline & 4 & $2.01 \mathrm{E} 4 \pm 2.00 \mathrm{E} 4^{\mathrm{a}}$ & $5.00 \mathrm{E} 5 \pm 5.00 \mathrm{E}^{\mathrm{a}}$ & $1.01 \mathrm{E} 4 \pm 9.97 \mathrm{E}^{\mathrm{a}}$ & $2.08 \mathrm{E} 8 \pm 1.22 \mathrm{E} 8^{\mathrm{b}}$ & 0.04 \\
\hline & 6 & $3.90 \mathrm{E} 3 \pm 3.80 \mathrm{E}^{\mathrm{a}}$ & $1.79 \mathrm{E} 4 \pm 1.56 \mathrm{E} 4^{\mathrm{a}}$ & $1.53 \mathrm{E} 4 \pm 1.45 \mathrm{E} 4^{\mathrm{a}}$ & $5.60 \mathrm{E} 7 \pm 3.38 \mathrm{E} 7^{\mathrm{b}}$ & 0.04 \\
\hline & 8 & $1.52 \mathrm{E} 6 \pm 1.10 \mathrm{E} 6$ & $1.59 \mathrm{E} 6 \pm 1.13 \mathrm{E} 6$ & $4.75 \mathrm{E} 5 \pm 3.19 \mathrm{E} 5$ & $2.70 \mathrm{E} 7 \pm 2.63 \mathrm{E} 7$ & 0.69 \\
\hline & A & $4.55 \mathrm{E} 3 \pm 4.15 \mathrm{E} 3^{\mathrm{a}}$ & $1.45 \mathrm{E} 4 \pm 1.29 \mathrm{E} 4^{\mathrm{a}}$ & $2.15 \mathrm{E} 3 \pm 1.46 \mathrm{E} 3^{\mathrm{a}}$ & $3.71 \mathrm{E} 6 \pm 2.78 \mathrm{E}^{6}{ }^{\mathrm{b}}$ & 0.001 \\
\hline & $\mathbf{P}_{\text {Age }}$ & 0.24 & 0.28 & 0.21 & 0.13 & \\
\hline \multirow[t]{6}{*}{ Staph } & 2 & $3.00 \mathrm{E} 4 \pm 9.97 \mathrm{E} 3$ & $1.44 \mathrm{E} 4 \pm 9.64 \mathrm{E} 3$ & $1.12 \mathrm{E} 4 \pm 9.67 \mathrm{E} 3$ & $3.00 \mathrm{E} 4 \pm 9.97 \mathrm{E} 3$ & 0.53 \\
\hline & 4 & $2.00 \mathrm{E} 4 \pm 2.00 \mathrm{E} 4$ & $1.17 \mathrm{E} 4 \pm 8.41 \mathrm{E} 3$ & $1.74 \mathrm{E} 3 \pm 1.18 \mathrm{E} 3$ & $1.37 \mathrm{E} 5 \pm 9.49 \mathrm{E} 4$ & 0.41 \\
\hline & 6 & $9.73 \mathrm{E} 2 \pm 9.63 \mathrm{E} 2$ & $1.17 \mathrm{E} 4 \pm 1.16 \mathrm{E} 4$ & $4.67 \mathrm{E} 3 \pm 4.66 \mathrm{E} 3$ & $4.49 \mathrm{E} 4 \pm 2.30 \mathrm{E} 4$ & 0.33 \\
\hline & 8 & $1.18 \mathrm{E} 5 \pm 9.44 \mathrm{E} 4$ & $2.12 \mathrm{E} 5 \pm 1.09 \mathrm{E} 5$ & $1.10 \mathrm{E} 5 \pm 9.68 \mathrm{E} 4$ & $3.07 \mathrm{E} 5 \pm 9.32 \mathrm{E} 4$ & 0.45 \\
\hline & A & $1.01 \mathrm{E} 4 \pm 9.98 \mathrm{E} 3^{\mathrm{a}}$ & $7.80 \mathrm{E} 3 \pm 3.68 \mathrm{E} 3^{\mathrm{a}}$ & $1.09 \mathrm{E} 4 \pm 9.71 \mathrm{E} 3^{\mathrm{a}}$ & $2.18 \mathrm{E} 5 \pm 1.05 \mathrm{E} 5^{\mathrm{b}}$ & 0.02 \\
\hline & $\mathbf{P}_{\text {Age }}$ & 0.45 & 0.7 & 0.47 & 0.12 & \\
\hline
\end{tabular}

other sites comparable. This pattern of distribution was the same before and after weaning. Differences were not detected between the contents and mucosa of the small intestine at any age or for any of the groups studied (all $p>0.20$ ). In other species adherent populations differ from those present in the lumen (Oli et al. 1998, our unpublished data for pigs, dogs, cats). The populations adherent to the mucosa are more likely to be permanent than those in lumenal contents, and may play a more important role in resisting colonization by introduced bacteria, whether pathogenic or beneficial.
Following a previous approach (Oli et al. 1998), additional insights of age effects were obtained by calculating differences between densities of total anaerobes minus Enterobacteriaceae in colon contents. Values for suckling kits were lower than those for animals eating the solid diet $(p<0.01)$. This provides further evidence that the Enterobacteriaceae represent a higher proportion of the GIT microbiota during suckling. This was particularly evident at 2 weeks of age when densities of Enterobacteriaceae in the colon actually exceeded those for anaerobes $(p<0.005)$. At all other ages total 
anaerobes in the colon exceeded densities of Enterobacteriaceae. Similarly, the proportions of aerobes in the colon represented by Enterobacteriaceae were greater during suckling (74\%) compared to weaned animals and adults $(23 \% ; \mathrm{p}<0.02)$.

In other species, higher proportions of lactobacilli and other lactic acid bacteria relative to Enterobacteriaceae are thought to be advantageous (Gibson \& Roberfroid 1995). There is a need to better understand the health implications of the presence of proportionally more Enterobacteriaceae during early development of mink, particularly since so many potential pathogens are members of the family.

Diet influences. Only little is known about the responses of the microbiota in the GIT of carnivores to changes in the quantity and quality of dietary inputs. Our results provide some of the first data that show how quantitative and qualitative characteristics of the diet can influence the bacteria present throughout the GIT of a carnivore (Table 3). The use of a sterile diet minimized the contribution of dietary contaminants, which are likely to have important influences on GIT bacterial populations in mink fed diets formulated with offal and other feed byproducts that are heavily colonized by bacteria. Introduced bacteria can be an important determinant of the composition of the mink GIT bacteria (Pedersen \& Jørgensen 1992). Even though a sterile diet was used, it is not possible to identify species that are indigenous to a region of the GIT, those that are continually introduced by grooming or from other environmental sources, or originate from a more proximal GIT region and are detected as transients in distal regions.

When all regions were pooled, diet effects were not detected for total anaerobes and Enterobacteriaceae. However, aerobes were higher in mink fed the diet with FOS, but only when compared to mink that were deprived of food $(p<0.05)$. Although diet effects were not detected for the Staphylococci when the individual diets were compared, pooled results for the diets with added fiber (cellulose and FOS) showed lower densities of staphylococci compared to mink fed the control diet and food deprived.

The lactobacilli were responsive to diet $(p<0.02)$. Mink that were food deprived or fed the diet without added fiber had lactobacilli in only 6 of 16 and 7 of 16 sample sites, respectively. Including FOS and cellulose into the cat feed increased the number of sample sites with detectable lactobacilli to 14 of 16 and 11 of 12 sample sites.

Diet did not alter the general pattern for regional distribution of bacteria along the GIT, with the highest densities of bacteria enumerated in the contents of the colon of mink from all 4 diet groups. However, the magnitude of differences between regions differed among the treatments. For example, significant regional differences were not detected for any bacterial groups when mink were food deprived. Therefore, to obtain more detailed insights about dietary influences, we examined the effects of diet within each of the four samples obtained from each mink.

Populations of anaerobes, aerobes, Enterobacteriaceae, lactobacilli, and staphylococci in the stomach did not differ between diet groups (all p's $>0.35$ ). Diet effects were not detected for Enterobacteriaceae in any of the other sample sites (p's $<0.30)$. The only detected significant effect of diet was the lower staphylococci densities in the colon of mink fed the diet with FOS. Diet had no significant effects $(p \leq 0.10)$ for the densities of aerotolerant forms in the contents and mucosa of the small intestine, with counts tending to be lower for mink fed the diet with cellulose.

These findings indicate that even though food rapidly passes through the GIT of mink, the 
Table 3. Densities of anaerobes (Anaer), aerobes (Aer), Enterobacteriaceae (Ent), and staphylococc1 (Staph) in the 4 sample sites of adult mink fed the commercial cat food (Cont), food deprived for $36 \mathrm{~h}$ (FD) or fed for 6 weeks the control diet with oligofructose $(\mathrm{C}+\mathrm{OF})$ or cellulose $(\mathrm{C}+\mathrm{C}) . \mathrm{P}_{\mathrm{Diet}}$ is the $\mathrm{P}$ value for the effect of diet in each of the 4 sample sites, and $P_{\text {Reg }}$ is for the effect of region. Values with different letter superscripts are significant different with respect to regions, whereas numbers indicate differences between diets $(p<0.05)$.

\begin{tabular}{|c|c|c|c|c|c|c|}
\hline Group & Diet & Stomach & $\begin{array}{l}\text { Small Intestine } \\
\text { Contents }\end{array}$ & $\begin{array}{l}\text { Small Intestıne } \\
\text { Mucosa }\end{array}$ & Colon & $P_{\text {Reg }}$ \\
\hline \multirow[t]{5}{*}{ Anaer } & Cont & $1.30 \mathrm{E} 7 \pm 1.29 \mathrm{E} 7$ & $1.43 \mathrm{E} 7 \pm 1.20 \mathrm{E} 7$ & $5.60 \mathrm{E} 6 \pm 5.53 \mathrm{E} 6$ & $1.60 \mathrm{E} 8 \pm 6.35 \mathrm{E} 7$ & 0.33 \\
\hline & FD & $1.04 \mathrm{E} 6 \pm 9.87 \mathrm{E}^{\mathrm{a}}$ & $3.59 \mathrm{E} 6 \pm 3.47 \mathrm{E}^{\mathrm{ab}}$ & $983 \mathrm{E} 6 \pm 8.53 \mathrm{E}^{\mathrm{ab}}$ & $2.45 \mathrm{E} 7 \pm 2.06 \mathrm{E} 7^{b}$ & 0.15 \\
\hline & $\mathrm{C}+\mathrm{OF}$ & $2.28 \mathrm{E} 6 \pm 1.92 \mathrm{E}^{\mathrm{a}}$ & $7.76 \mathrm{E} 6 \pm 468 \mathrm{E}^{\mathrm{a}}$ & $2.94 \mathrm{E} 6 \pm 1.72 \mathrm{E}^{\mathrm{a}}$ & $3.12 \mathrm{E} 8 \pm 1.29 \mathrm{E} 8^{\mathrm{b}}$ & 0.02 \\
\hline & $\mathrm{C}+\mathrm{C}^{1}$ & $6.2 \mathrm{E} 6$ & $4.7 \mathrm{E} 4$ & -- & $1.98 \mathrm{E} 9$ & 0.72 \\
\hline & $\mathrm{P}_{\text {Diet }}$ & 0.45 & 0.63 & 0.72 & 0.10 & \\
\hline \multirow[t]{5}{*}{ Aer } & Cont & $292 \mathrm{E} 6 \pm 2.82 \mathrm{E} 6$ & $5.69 \mathrm{E} 6 \pm 3.41 \mathrm{E}^{12}$ & $657 \mathrm{E} 6 \pm 6.48 \mathrm{E}^{12}$ & $1.53 \mathrm{E} 8 \pm 5.09 \mathrm{E} 7$ & 0.17 \\
\hline & FD & $4.98 \mathrm{E} 5 \pm 4.94 \mathrm{E} 5$ & $629 \mathrm{E} 4 \pm 3.73 \mathrm{E} 4^{1}$ & $9.04 \mathrm{E} 6 \pm 8.52 \mathrm{E}^{1}$ & $492 \mathrm{E} 7 \pm 3.72 \mathrm{E} 7$ & 012 \\
\hline & $\mathrm{C}+\mathrm{OF}$ & $1.45 \mathrm{E} 6 \pm 7.93 \mathrm{E} 5^{\mathrm{a}}$ & $7.36 \mathrm{E} 6 \pm 3.79 \mathrm{E}^{2 \mathrm{ab}}$ & $2.82 \mathrm{E} 6 \pm 1.53 \mathrm{E} 6^{1 \mathrm{a}}$ & $225 \mathrm{E} 8 \pm 1.95 \mathrm{E} 8^{\mathrm{b}}$ & 0.05 \\
\hline & $\mathrm{C}+\mathrm{C}$ & $1.05 \mathrm{E} 6 \pm 102 \mathrm{E}^{\mathrm{a}}$ & $6.23 \mathrm{E} 4 \pm 3.11 \mathrm{E} 4^{2 \mathrm{a}}$ & $137 \mathrm{E} 4 \pm 7.28 \mathrm{E} 3^{2 \mathrm{a}}$ & $305 \mathrm{E} 8 \pm 148 \mathrm{E} 8^{b}$ & 0002 \\
\hline & $P_{\text {Diet }}$ & 0.59 & 0.09 & 0.10 & 042 & \\
\hline \multirow[t]{5}{*}{ Enter } & Cont & $4.55 \mathrm{E} 3 \pm 4.15 \mathrm{E}^{\mathrm{a}}$ & $1.45 \mathrm{E} 4 \pm 129 \mathrm{E} 4^{\mathrm{a}}$ & $2.15 \mathrm{E} 3 \pm 1.46 \mathrm{E} 3^{\mathrm{a}}$ & $371 \mathrm{E} 6 \pm 2.78 \mathrm{E} 6^{\mathrm{b}}$ & 0.001 \\
\hline & FD & $2.57 \mathrm{E} 5 \pm 209 \mathrm{E} 5$ & $3.03 \mathrm{E} 4 \pm 1.86 \mathrm{E} 4$ & $439 \mathrm{E} 6 \pm 4.37 \mathrm{E} 6$ & $4.10 \mathrm{E} 7 \pm 3.97 \mathrm{E} 7$ & 041 \\
\hline & $\mathrm{C}+\mathrm{OF}$ & $1.07 \mathrm{E} 3 \pm 9.75 \mathrm{E} 2^{\mathrm{a}}$ & $7.75 \mathrm{E} 5 \pm 7.75 \mathrm{E}^{\mathrm{a}}$ & $6.50 \mathrm{E} 5 \pm 6.50 \mathrm{E}^{\mathrm{a}}$ & $1.56 \mathrm{E} 7 \pm 1.51 \mathrm{E} 7^{\mathrm{b}}$ & 004 \\
\hline & $\mathrm{C}+\mathrm{C}$ & $101 \mathrm{E} 5 \pm 9.95 \mathrm{E} 4^{\mathrm{a}}$ & $4.20 \mathrm{E} 4 \pm 206 \mathrm{E} 4^{\mathrm{a}}$ & $7.67 \mathrm{E} 3 \pm 3.38 \mathrm{E} 3^{\mathrm{a}}$ & $8.60 \mathrm{E} 7 \pm 3.21 \mathrm{E} 7^{\mathrm{b}}$ & 0.003 \\
\hline & $P_{\text {Diet }}$ & 0.39 & 0.88 & 0.32 & 0.24 & \\
\hline \multirow[t]{5}{*}{ Staph } & Cont & $1.01 \mathrm{E} 4 \pm 9.98 \mathrm{E}^{\mathrm{a}}$ & $780 \mathrm{E} 3 \pm 3.68 \mathrm{E} 3^{\mathrm{a}}$ & $1.09 \mathrm{E} 4 \pm 971 \mathrm{E}^{\mathrm{a}}$ & $2.18 \mathrm{E} 5 \pm 105 \mathrm{E} 5^{1 \mathrm{a}}$ & 002 \\
\hline & FD & $830 \mathrm{E} 3 \pm 7.90 \mathrm{E} 3$ & $7.50 \mathrm{E} 2 \pm 4.01 \mathrm{E} 2$ & $8.05 \mathrm{E} 4 \pm 7.56 \mathrm{E} 4$ & $9.35 \mathrm{E} 4 \pm 6.93 \mathrm{E} 4^{1}$ & 0.19 \\
\hline & $\mathrm{C}+\mathrm{OF}$ & $717 \mathrm{E} 2 \pm 471 \mathrm{E} 2$ & $219 \mathrm{E} 5 \pm 1.94 \mathrm{E} 5$ & $780 \mathrm{E} 2 \pm 708 \mathrm{E} 2$ & $214 \mathrm{E} 3 \pm 136 \mathrm{E} 3^{2}$ & 029 \\
\hline & $\mathrm{C}+\mathrm{C}$ & $373 \mathrm{E} 2 \pm 362 \mathrm{E} 2^{\mathrm{a}}$ & $437 \mathrm{E} 3 \pm 383 \mathrm{E}^{\mathrm{ab}}$ & $673 \mathrm{E} 2 \pm 6.63 \mathrm{E} 2^{\mathrm{a}}$ & $356 \mathrm{E} 5 \pm 327 \mathrm{E} 5^{1 \mathrm{~b}}$ & 004 \\
\hline & $\mathrm{P}_{\text {Diet }}$ & 0.82 & 0.54 & 0.35 & 0.03 & \\
\hline
\end{tabular}

${ }^{1}$ Due to technical problems, total anaerobes were enumerated in only one of the mink fed the diet with cellulose, and only in the contents of the stomach, small intestine, and colon

quantitatıve and qualitative characteristics of dietary inputs can influence the bacterial groups present in the lumen of the gastrointetinal tract and those associated with the mucosa. The effects of diet are specific in that the different populations of bacteria have varying patterns of responses to diet, and these responses are not consistent in all regions of the GIT.

\section{Conclusions and perspectives}

The bacterial populations in the GIT of mink are dynamic, varying over time and in response to changes in dietary inputs. The present study examined only a few of the groups that could be important components of the bacterial assemblages present in the different regions of the mink GIT. When we sum the densities of the specific groups, they represent only a small percentage of the total bacterial densities, highlightıng the need to better characterize the bacterial populations in the GIT of mink. This lack of information is true for other carnivores.

In other species, some of the most dramatic changes in GIT bacterial assemblages take place during the first days after birth. The 
higher proportion of bacteria represented by Enterobacteriaceae at 2 weeks compared to older mink suggests there are changes in the GIT microbiota during early development of mink. It remains unknown what the changes are and how they might be influenced by colostrum and milk, changes in GIT characteristics, and competitive interactions among the different bacterial groups.

There are health implications associated with the presence of bacteria perceived as being beneficial and pathogenic (Gibson \& Roberfroid 1995). Our findings for diet effects are similar to results from studies with humans (Williams et al. 1993), dogs (Willard et al. 1994), and cats (Sparkes et al. 1998), and show that diet can be used to promote higher densities of bacterial groups perceived as being beneficial and reduce potential pathogens. The ability to adventitiously manage the GIT bacteria by dietary intervention or introduction of beneficial species (Pedersen \& Jørgensen 1992) may be particularly useful during weaning when risks of morbidity and mortality from disease are higher.

\section{Acknowledgement}

The Iams Company is acknowledged for providing the food and the Danısh Fur Breeders Association for financial support We would like to thank Carol Williams for assistıng with the microbiology and Mike Bassett for anımal care and handlıng

\section{References}

Add $l s$ Typertrophy of the gastro-intestinal tract and high residue diets Am. J. Physiol. 1932, 99, 417-423.

Clausen $T$ Undersøgelse af aerobe bakteriers forekomst 1 tarmkanalen hos mınkhvalpe. Faglıg Årsberetning. (Presence of aerobic bacteria in the gastrointestinal tract of mink). Dansk Pelsdyravlerforenıng, 1988, 261-264.
Davis CP, Cleven D, Balish E, and Yale CE Bacterial association in the gastrointestinal tract of beagle dogs. Appl Env. Microbiol. 1977, 34, 194-206

Glbson GR, Roberfrovd $M B$. Dietary modulation of the human colonic microbiota introducing the concept of prebiotics J Nutr. 1995, 125, 14011412.

Jensen BB, Clausen $T$ Den mikrobielle aktıvitet 1 mave-tarmkanalen hos mınk Faglig Årsberetning (The microbic activity in the gastrointest1nal tract of mink) Dansk Pelsdyravlerforenıng, 1993/1994, 186-197.

Olı MW, Petschow BW, Buddington RK Evaluation of fructooligosaccharide supplementation of oral electrolyte solutions for treatment of diarrhea. Recovery of the intestinal bacteria. Dig Dis. Sc1. 1998, 43, 138-147

Pedersen $K$, Jørgensen $K$ Lactıc acid bacteria for mink. Colonization and persistence of Enterococcus faecium Cernelle 68 in the digestive tract of mink. Acta vet. scand. 1992, 33, 95-103

Pedersen K, Jørgensen K, Henriksen $P$ Evidence for the colonization of lactic acid bacteria in the gastrointestınal tract of suckling mink. Acta vet. Scand. 1994, 35, 439-443

Sparkes AH, Papasouliotıs K, Sunvold G, Werrett $G$, Gruffydd-Jones EA, Egan K, Gruffydd TJ, Reinhart $G$ The effect of dietary supplementation with fructo-oligosaccharides on the faecal floral of healthy cats. Am. J. Vet Res 1998, 59, 434440.

Summanen P, Baron EJ, Citron DM, Strong C, Wexler HM, Finegold SM Wadsorth Anaerobic Bacter1ology Manual, 3rd Ed Star Publ Co, Los Angeles, CA, 1993

Swords WE, Wu C-C, Champlin FR, Buddington RK Postnatal changes in selected bacterial groups of the pig colonic microflora. Biol. Neonate 1993, 63, 191-200.

Tannock GW, Blumershine R, Archibald R Demonstration of epithelium-associated microbes in the oesophagus of prgs, cattle, rats, and deer FEMS Microbiol. Ecol. 1987, 45, 199-203

Waechter KG, Henrıksen $P$ Mikrobiologiske undersøgelser af mink og ræve. (Investigation of microbes in mink and foxes) Faglig Årsberetning. Dansk Pelsdyravlerforening, 1984, 179-189.

Willard MD, Simpson RB, Delles EK, Cohen ND, Fossum TW, Kolp D, Reinhart $G$. Effects of d1etary supplementation of fructo-oligosaccharides on small intestinal bacterial overgrowth in dogs Am. J Vet. Res 1994, 55, 654-658. 


\section{Sammendrag \\ Mikrobiel aktivitet 1 minkens mave-tarmkanal Be- tydning af alder og foder}

Det totale antal af aereotolerante og anaerobıske bakterier samt antallet af entrobakterier, lactobaciller, stafylokokker, salmonella og shigella samt campylobakterier blev målt 1 indholdet fra mave, tyndtarm (samt dennes mucosa) og kolon. Undersøgelsen blev foretaget på mınkhvalpe 1 alderen 2 t1l 8 uger samt på udvoksede mink, der dels blev fodret med foder indeholdende forskellige typer og niveauer af fibre dels blev fastet 136 timer Den største bakterietæthed blev hos dyr 1 alle aldersgrupper fundet 1 kolon (op t $110^{8}$ kım per gram for det totale antal af anaerobe bakterier). Sammenlignet med andre pattedyr er dette dog 2-3 logaritmiske enheder lavere. For summen af de undersøgte regioner var der tale om en sıgnifikant aldersrelateret stıgning $(\mathrm{p}<0.05) 1$ antallet af anaerobe, aerobe og stafylokokker. Denne stignıng forløb parallelt med fravænnıngen Mængden af entrobakterier ændredes 1 kke med alderen Isolater af laktobaciller var få, men blev oftere fundet efter fravænnıng 1sær hos udvoksede mınk, der blev fodret med foder tilsat fiber Campylobakter blev kun fundet ved 2 ugers alderen, mens salmonella og shigella $1 \mathrm{kke}$ blev fundet 1 nogle af isolaterne fra de undersøgte mink. Den totale bakterietæthed, den relative fordeling mellem bakteriegrupperne samt de alders- og foderrelaterede effekter var forskellige fra forholdene undersøgt hos andre, hovedsagelig altædende pattedyr. Disse forskelle kan henføres til foderets sammensætnıng og korte passagetıd hos rovdyr.

(Recelved April 15, 1998, accepted September 10, 1998)

Reprints may be obtained from: R K. Buddıngton, Department of Biological Sciences, Mississippi State University, Mississippi State, MS 39762-1759 USA. E-mail: rkbl@ra.msstate edu, tel: 6013257580, fax. $601325-7939$. 